\title{
FOUCAULT E A ÉTICA DA INFÂMIA ${ }^{1}$
}

\author{
FOUCAULT AND THE ETHICS OF INFAMY
}

\author{
TOMÁS MENDONÇA DA SILVA PRADO² \\ (USJT, Brasil)
}

\begin{abstract}
RESUMO
Trata-se, neste trabalho, de investigar se um conjunto de práticas examinadas por Michel Foucault pode ser caracterizado, segundo nossos próprios termos, como uma ética infame. Tecida por meio dos conceitos de discurso e poder, e inscrita em arquivos históricos, ela subverte a compreensão teórica habitual de poder travado entre diferentes classes ou raças, reconhecendo formas heterogêneas de acordos e desacordos entre grupos em vista da normatização ou da exclusão de indivíduos. Constituída por discursos que revelam pequenos segredos e disputas do cotidiano, a ética da infâmia é uma rede de relações que parte de um apelo vitimado a instâncias supostamente altruístas em nome da salvação de indivíduos perdidos na liberdade que reivindicaram para si próprios.

Palavras-chave: Discurso. Poder. Ética. Infâmia.
\end{abstract}

\begin{abstract}
This paper aims to investigate if a set of practices examined by Michael Foucault may be characterized, according to our own terms, as an infamous ethics. Woven through the concepts of discourse and power, and registered in historical archives, it subverts the current theoretical comprehension of power disputed among different classes or races, recognizing heterogeneous ways of agreements and disagreements among groups in view of the norming or exclusion of individuals. Composed by discourses that reveal small secrets and everyday disputes, the ethics of infamy is a network of relations that begins in a victimized plea to supposedly altruistic instances on behalf of the salvation of individuals lost on their own claimed freedom.
\end{abstract}

Keywords: Discourse. Power. Ethics. Infamy.

Os doutores do Grande Veículo ensinam que o essencial no universo é a vacuidade. Têm inteira razão no que diz respeito à minúscula parte do universo que é o presente livro. Patíbulos e corsários o povoam e a palavra infâmia do título é retumbante, mas por baixo dessa balbúrdia não há nada. Não é mais que aparência, que uma superficie de imagens. (BORGES, 1978, p. 30)

\section{Introdução a uma contra-história}

A relação entre discurso e poder, conceitos fundadores da genealogia de Michel Foucault, não é de caráter alegórico. O discurso não é um signo do poder. Como afirma o filósofo no texto "A vida dos homens infames": "Esses discursos realmente atravessaram vidas; essas existências foram efetivamente riscadas e perdidas nessas palavras." 
(FOUCAULT, 2006, p. 207). O discurso não é uma expressão do poder; não é um acontecimento tardio. Trata-se, neste trabalho, de investigar em que consistiria para o autor de Vigiar e punir um conjunto de práticas que, segundo nossos termos, talvez possamos designar ética infame, tecida por meio destes conceitos e diagnosticada em arquivos históricos.

\begin{abstract}
Não procurei reunir textos que seriam, melhor que outros, fiéis à realidade, que merecessem ser guardados por seu valor representativo, mas textos que desempenharam um papel nesse real do qual falam, e que se encontram, em contrapartida, não importa qual seja sua exatidão, sua ênfase ou sua hipocrisia, atravessados por ela: fragmentos de discurso carregando os fragmentos de uma realidade da qual fazem parte (FOUCAULT, 2006, p. 206).
\end{abstract}

Nada, portanto, de alegórico. O procedimento arqueológico, que buscava decifrar uma experiência originária de linguagem e um saber a um tempo fundamental e subjacente às positividades históricas, é invertido. O filósofo agora reconhece na sua metodologia de outrora uma dedicação ao "mesmo", ao obscurantismo de uma linguagem hegemônica. Em $A s$ palavras e as coisas, o povo era uma soma de forças, uma grande unidade alegórica, como um gigante. Se ele estava na origem da linguagem, é somente na medida em que unido produzia, de suas trocas espontâneas, as experiências que emprestariam precisão aos termos. Porém, a análise das formações discursivas, por outro lado, dedicada aos enunciados, à miudeza de suas diferenciações - "raridades e acúmulos" -, não trará uma visão do poder centralizadora; não se contentará tampouco com a oposição de classes. Respeitar a positividade dos discursos exige não sobrecarregá-los nem com uma pretensa experiência arcaica com a linguagem nem com unidades de forças, o que conduzirá Foucault a reconhecer posições convergentes, antes não imaginadas, entre o soberano e os seus súditos, assim como a encontrar diferenças e abusos de poder onde todos são iguais na infâmia.

Em $A$ arqueologia do saber, Foucault renuncia a "ver no discurso um fenômeno de expressão" (FOUCAULT, 2008, p. 61). A decifração, antes a atividade correspondente à linguagem em sua abordagem alegórica, será reelaborada. Ela não transfigurará as aparências em favor de uma verdade preservada dos conflitos de superfície. Ela recobrará, do esquecimento, os acontecimentos que atravessaram os discursos. $\mathrm{O}$ resgate da memória não será mais o resgate do sentido, mas o resgate do acontecimento.

Estes quatro termos, leitura - traço - decifração - memória (qualquer que seja o privilégio que se dê a um ou outro, e qualquer que seja a extensão metafórica que se lhe atribua e que lhe permita reconsiderar os três outros), definem o sistema que permite, usualmente, arrancar o discurso passado de sua inércia e reencontrar, num 
momento, algo de sua vivacidade perdida. (FOUCAULT, 2008, p. 139).

A decifração não se dirige mais ao símbolo - não é, fundamentalmente, interpretação. Ela se dirige à memória, à sua "vivacidade perdida", que só pode ser reconhecida e demonstrada na esfera do próprio discurso. Também no curso Em defesa da sociedade, de 1976, Foucault nos fala de uma nova tarefa de decifração. Aqui se encontrará indícios que sugerem um retrocesso. Ele falará de "máscaras" e "segredos", mas em diferente sentido, porque os discursos foram apropriados por um interesse específico que se autodenomina interesse de todos. O discurso histórico predominante serviu a uma perspectiva, e será preciso deslocar essa apropriação. Revelar os segredos será desnudar o pretexto de neutralidade dos discursos - a verdadeira máscara.

Portanto, o papel da história será o de mostrar que as leis enganam, que os reis se mascaram, que o poder ilude e que os historiadores mentem. Não será, portanto, uma história da continuidade, mas uma história da decifração, da detecção do segredo, da devolução da astúcia, da reapropriação de um saber afastado ou enterrado. Será a decifração de uma verdade selada (FOUCAULT, 2005, p. 84).

É preciso desapropriar o terreno histórico da historiografia tradicional, porque nela não estão todos contemplados. O trabalho parte da desconstrução de um postulado, "de que a história dos fortes traz consigo a história dos fracos" (FOUCAULT, 2005, p. 81). Será preciso, em seu lugar, empregar um novo, o da "heterogeneidade". Não está em questão uma nova forma de interpretação, mas encontrar um meio de dar a cada um o que é seu, admitindo a coexistência de uma multiplicidade de vidas oprimidas pela esfera política que deveria representá-las.

Surge, com isso, o interesse que, um ano mais tarde, em 1977, dará origem ao pequeno e inversamente grandioso trabalho, já referido, "A vida dos homens infames" - uma nova narrativa, dedicada a uma "contra-história": "Ela vai ser o discurso daqueles que não têm a glória, ou daqueles que a perderam e se encontram agora, por uns tempos talvez, mas por muito tempo decerto, na obscuridade e no silêncio." (FOUCAULT, 2005, p. 82).

\section{Uma antologia de existências}

O texto "A vida dos homens infames", pela primeira vez publicado na coletânea Les cahiers du chemin, apresenta arquivos que já teriam sido consultados por Foucault em ethic@-Florianópolis, Santa Catarina, Brasil, v.13, n.2, p.323-338, jul./dez., 2014. 
pesquisas anteriores, mas que não foram diretamente citados. Ele deveria acompanhar, na forma de introdução, uma seleção de fragmentos desses arquivos, plano não inteiramente vingado. Foucault afirma que a publicação em compêndio desse material é um projeto ambicionado desde História da loucura, e ele será retomado dois anos antes de sua morte, com a inserção de Le désordre des familles na coleção Archives. Ao longo do seu trabalho, o exame de documentos históricos, tais como "arquivos de internamento, da polícia, das petições ao rei e das cartas régias com ordem de prisão" (FOUCAULT, 2006, p. 211) ganhou progressivamente importância, contribuindo na tarefa de problematizar abordagens tradicionais da história. Com tudo isso, em "A vida dos homens infames" será dado a esse material um tratamento ainda diferenciado: "Este não é um livro de história. (...) É uma antologia de existências.” (FOUCAULT, 2006, p. 203).

\footnotetext{
Mathurin Milan, posto no hospital de Charenton no dia 31 de agosto de 1707: "Sua loucura sempre foi a de se esconder de sua família, de levar uma vida obscura no campo, de ter processos, de emprestar com usura e a fundo perdido, de vaguear seu pobre espírito por estradas desconhecidas, e de se acreditar capaz das maiores ocupações" (FOUCAULT, 2006, p. 204).
}

A "antologia de existências" exige de sua leitura que não se produza categorias, que não se aprisione essas vidas em classes. Se História da loucura revelou uma constelação de classes distintas sem qualquer ligação intrínseca - blasfemadores, alquimistas, libertinos, leprosos, vagabundos, prostitutas, entre outros - vemos agora, sob o signo do nome próprio, a denúncia do esforço, do mesmo modo estapafúrdio, de institucionalizar em vagos conceitos um homem que busca "vaguear seu pobre espírito por estradas desconhecidas", de censurar o sonho de alguém que aparenta "se acreditar capaz das maiores ocupações". Esta é a loucura que teria acometido Mathurin Milan.

\footnotetext{
Jean Antoine Touzard, posto no Chateau de Bicêtre, no dia 21 de abril de 1701: "Recoleta apóstata, sedicioso capaz dos maiores crimes, sodomita, ateu, se é que se pode sê-lo; um verdadeiro monstro de abominação que seria menos inconveniente sufocar do que deixar livre." (FOUCAULT, 2006, p. 204).
}

A crítica às metodologias tradicionais da historiografia e às teorias dedicadas ao discernimento da história universal sempre mobilizou o pensamento de Foucault, com destaque para as obras As palavras e as coisas e A arqueologia do Saber, que contrariam as compreensões lineares e teleológicas. Porém, o que ele pretende nesse ponto não é lançar um olhar alternativo sobre a história em geral ou a história de uma instituição e de uma disciplina. 
É dada atenção às datas mais do que às épocas: 21 de abril de 1701. O que ele pretende é enxergar existências lá onde elas foram censuradas: "apóstata, sedicioso, sodomita, ateu, se é que se pode sê-lo". Na virada para o século XVIII, Jean Antoine Touzard foi preso no Chateau de Bicêtre por sê-lo.

"A vida dos homens infames" é um texto particularmente marcado por uma intervenção pessoal que implica Foucault a esses personagens singulares e que seduz o leitor a se implicar também nessa antologia de existências. Sua trama revela mais do que uma inovação metodológica a nos reposicionar como herdeiros de um mundo desconhecido. O que o caracteriza é a atenção dada a experiências singulares. Não se trata de depreender da história uma lição moral ou um novo método de análise, mas de reunir testemunhos e, com uma estranha comoção filosófica, se juntar a eles:

Eu ficaria embaraçado em dizer o que exatamente senti quando li esses fragmentos e
muitos outros que lhes eram semelhantes. Sem dúvida, uma dessas impressões das
quais se diz que são "físicas", como se pudesse haver outras. E confesso que essas
"notícias", surgindo de repente através de dois séculos de silêncio, abalaram mais
fibras em mim do que o que comumente chamamos literatura, sem que possa dizer,
ainda hoje, se me emocionei mais com a beleza desse estilo clássico, drapeado em
algumas frases em torno de personagens sem dúvida miseráveis, ou com os
excessos, a mistura de obstinação sombria e perfídia dessas vidas das quais se
sentem, sob as palavras lisas como a pedra, a derrota e o afinco. (FOUCAULT, 2006,
p. 204).

Homens e mulheres que, na efemeridade de suas vidas, encontraram desprezo e violência são desafortunados também no esquecimento. Sem intervir nos grandes acontecimentos da história, sem alcançar glórias, nada restaria não fossem os pequenos "fragmentos" de arquivos, essas "notícias" que, quase dois séculos mais tarde, receberão na leitura os cuidados que não receberam no momento da escrita. Não uma atenção imparcial, mas um gesto admirado. Isso é o que faz de "A vida dos homens infames" um dos mais belos textos de Foucault - e possivelmente um dos mais ousados.

Recuperemos, como ponto de partida e caracterização desse trabalho, a tensão entre a recorrente ideia de um "acaso" revelador dessas existências e a sugestão do autor de que tal conjunto de relatos formaria um "herbário"3 - imagem chocante, provocativa, que alude a essas vidas como se fossem uma coleção de vegetais a serviço da taxinomia clássica. Contudo, em vez de revelar critérios que explicitassem a organização do quadro, Foucault apresenta os critérios motivadores apenas do seu interesse. A tensão provocada pelo texto não opõe, afinal, o acaso à ciência. A tensão surge de um encontro mais espantoso, um 
reconhecimento recusado - revelação cujo esperado refúgio não se pode buscar em parte alguma, pois acontece no confronto da vida consigo mesma, em vidas reveladas em seus atributos miúdos, em atritos de casais, diferenças entre vizinhos, todo o obscuro mundo privado e sem importância capaz de, entre paredes ou no alcance do grito, se multiplicar em casos infinitos e quase idênticos. Vidas reveladas em si mesmas, quiçá a outras vidas que não sabem muito de si. São todas essas coisas sem relevância, do cotidiano que é alheio à passagem do tempo e à tentativa de aprisioná-lo, que de súbito mais interessam aos olhos que se voltam do futuro. Foucault provoca a tensão de uma experiência genuína com o passado, porque o passado assim exposto nos lembra do presente.

Como disseminar a comoção que tal experiência suscita? O que provoca essa tensão? É possível analisar os casos, conceituá-los, esclarecê-los, abarcá-los e, finalmente, assegurarmo-nos de uma suposta fórmula sob a qual eles nos permitam fugir do encontro temeroso com o mesmo destino - infame? Foucault não nos dá regras para escapar. Ao contrário, dirá que "entre essas pessoas sem importância e nós que não a temos mais do que eles, nenhuma relação de necessidade" (FOUCAULT, 2006, p.210). Mas os critérios da filosofia, os critérios da historiografia, mesmo da beleza literária, todas essas referências com as quais organizamos a relação do pensamento com o passado são revistas, são alteradas e não nos permitem saber em que posição, então, nos enredamos. Filosofia, história, crítica literária? Foucault oferecerá as regras que organizaram a sua antologia e que esclarecem, a seus próprios olhos, o interesse que o trabalho desperta:

Foi para reencontrar alguma coisa como essas existências-relâmpagos, como esses poemas-vidas que eu me impus um certo número de regras simples:

- que se tratasse de personagens tendo existido realmente;

- que essas existências tivessem sido, ao mesmo tempo, obscuras e desventuradas;

- que fossem contadas em algumas páginas, ou melhor, algumas frases, tão breves quanto possível;

- que esses relatos não constituíssem simplesmente historietas estranhas ou patéticas, mas que de uma maneira ou de outra (porque eram queixas, denúncias, ordens ou relações) tivessem feito parte realmente da história minúscula dessas existências, de sua desgraça, de sua raiva ou de sua incerta loucura;

- e que do choque dessas palavras e dessas vidas nascesse para nós, ainda, um certo efeito misto de beleza e de terror. (FOUCAULT, 2006, p.205-206).

"Existências-relâmpagos", "poemas-vida": seriam essas as categorias encontradas por Foucault no quadro de sua própria comoção? "Personagens que tivessem realmente existido", que pertencessem a "uma peça na dramaturgia do real" (FOUCAULT, 2006, p. 206). E o que é isto, pertencer à "dramaturgia do real", senão ter uma existência "ao mesmo tempo obscura 
e desventurada"? Que o obscurantismo e o infortúnio da vida estivessem também na forma de seu relato, "tão breve quanto possível", como breve e sem importância foi a própria vida, e como se a vida fosse só o seu breve relato. É imperativo que essa desventura no relato não seja o que, no cotidiano, o alimenta, mas que o decida; e nascido dele, ao acaso, o destrua. $\mathrm{O}$ que surge de "queixas, denúncias, ordens" deve "ter feito parte realmente dessas histórias minúsculas dessas existências"; deve ter atravessado, decidido e desviado. Finalmente, Foucault quis, de todas as regras, que permanecesse um elemento desregrado, não reduzido a nenhuma outra: "do choque", "certo efeito misto de beleza e de terror".

O texto "A vida dos homens infames" reúne de forma particularmente precisa e generosa conceitos fundamentais para o filósofo: o poder, a história, o discurso, o sujeito temas por diversos modos já considerados em outras obras, mas que vemos agora implicados à infâmia, como se houvesse uma fábula ou uma ética da infâmia. Para esboçar essa diferença, recorremos à avaliação que ele faz de suas realizações anteriores, de seu próprio discurso precedente, e em referência aos mesmos arquivos já utilizados:

\begin{abstract}
O sonho teria sido o de restituir sua intensidade em uma análise. Na falta do talento necessário, por muito tempo remoí só a análise; tomei os textos em sua aridez; procurei qual tinha sido a sua razão de ser. (...) Mas as intensidades primeiras que me motivaram permaneciam do lado de fora. E uma vez que havia o risco delas não passarem para a ordem das razões, uma vez que meu discurso era incapaz de levá-las como caberia, o melhor não seria deixá-las na forma mesma que me fizeram sentila? (FOUCAULT, 2006, p. 204-205).
\end{abstract}

Diante da dificuldade de analisar os relatos, Foucault submeteu, em História da loucura, a constelação de tantas classes de personagens excluídos à análise de alguns conceitos, a razão, a desrazão e a linguagem. Em referência ao projeto de As palavras e as coisas, ele investigou a ordem por trás dos discursos, como um caminho indireto. Não conceitos universais, mas os conceitos-chaves de cada época. Há, porém, uma distância intransponível entre a "ordem das razões" e as "intensidades primeiras" de tal enfrentamento. No primeiro momento, o mais difícil era "deixá-las na forma mesma que me fizeram senti-la", mas isso não é um sentimentalismo pueril. Admitindo que há uma instância histórica que atravessa qualquer autoria, trata-se de reconhecer que ela atravessa o nosso próprio discurso. Trata-se da crítica a uma resistência tradicional, que é pôr-se num âmbito de transcendência; a dificuldade de incorporar aquilo mesmo de que é falado na teoria ou a respeito dos outros sobre a nossa inserção histórica. O estilo pessoal que carrega esse texto - mesmo os sentimentos nele contidos - não é somente um capricho, um efeito que o torna mais belo, 
porque denuncia a comum aflição dos autores por escapar à história por meio de um estilo de discurso que os proteja da transitoriedade e da força das circunstâncias, que os coloque em um lugar neutro, imparcial, mais próximo da verdade segundo quer tanto a ciência quanto a vulgata. A intensidade da escrita no texto em questão e a implicação explícita de seus afetos são marcas do compromisso do autor com a alteridade e não com a obra que viria salvá-lo de tudo o que ele vislumbra comprometido. Por paradoxal que essa constatação possa parecer, não é no rigor do formalismo teórico que o discurso encontra a história, mas comprometendose com ela, mostrando o que dela espera ou como é por ela atingido na medida em que a recebe, e a experiência mais radical será aquela em que ele é capaz de apresentá-la sem ser ele mesmo o porta-voz neutro de sua verdade. A ética da infâmia de alguma forma aponta para uma ética do discurso filosófico quando este se volta à análise da história.

\section{Status e infâmia}

A produção anterior foi insinuada como o remoer de uma análise árida, incapaz de apreender o que nos atrai àqueles relatos. Mas devemos reparar que não se trata de recusar a análise anterior, de reconhecer um equívoco, mas uma insuficiência - o critério é a aridez e não o erro. Se teorias foram edificadas, enquanto outras foram combatidas, não seria a hora de, não mais interpretar o que não estaria suficientemente claro, mas de simplesmente reunir e apresentar o que está esquecido, como uma atividade de curadoria da história?

Recordemo-nos das análises de Foucault sobre a autoria em "O que é um autor?”, de 1969. O foco de seu estudo é o jogo, o conjunto dos casos em que o autor é uma função dos discursos, sobretudo para o fim de conferir aos mesmos um maior status: "Sem dúvida, a esse ser de razão, tenta-se dar um status realista. Seria, no indivíduo, uma instância 'profunda', um poder 'criador', um 'projeto', o lugar originário da escrita.” (FOUCAULT, 2009, p. 276). A expressão "status realista" é curiosa. Sugere a ideia de que determinado discurso possui maior valor do que outro, na medida em que é proferido por alguém que é um sujeito mais real do que outrem. Ter status significa ser reconhecido em seu discurso, ser origem de uma escrita que deixa de pertencer apenas a si para atingir e transformar outras vidas.

Poder-se-ia dizer que há, em uma civilização como a nossa, um certo número de discursos que são providos da função "autor", enquanto outros são dela desprovidos. Uma carta particular pode ter um signatário, ela não tem um autor; um contrato pode 
ter um fiador, ele não tem autor. Um texto anônimo que se lê na rua em uma parede terá um redator, não terá um autor. A função autor é, portanto, característica do modo de existência, de circulação e de funcionamentos de certos discursos no interior de uma sociedade (FOUCAULT, 2009, p. 274).

Devemos reconhecer nesse estudo do texto de 1969, “O que é um autor?”, uma confluência temática com o texto "A vida dos homens infames", no qual deparamos com discursos sem lugar, que não deveriam circular e que por isso mesmo foram esquecidos, mas que, preservados para a consulta dos historiadores, de súbito assumem um valor jamais ambicionado quando foram escritos e arquivados. A diferença essencial consiste em uma espécie de inversão de posições entre quem fala e aquilo de que fala. No texto de 1969, o que é dito - uma obra literária, uma demonstração matemática ou a instituição de uma nova disciplina, como a psicanálise -, carrega o autor, dá a ele um renome, Proust, Galileu, Freud. Tendo certos discursos sido reconhecidos, outros proferidos pelos mesmos autores ou por quem a eles se vincule deverão compartilhar semelhante status. No texto de 1977, cujo foco é a infâmia, ou seja, o oposto ao status, é conferido ou subtraído status a um autor anteriormente aos discursos que ele profere. Será ligando-se ao status do rei que os ditos infames terão uma chance de serem recuperados séculos mais tarde. No entanto, ao contrário da forma como o discurso dos psicanalistas compartilha o status do discurso de Freud, o poder separa os infames do rei. Não há parentesco. As solicitações feitas ao rei visam uma pequena partilha do seu poder, mas o gesto deverá, tão subitamente cumprido, ser apagado, deixando rastros somente nos registros para controle nos órgãos administrativos do Estado.

"Fragmentos de discurso carregando os fragmentos de uma realidade da qual fazem parte" - palavras de Foucault em "A vida dos homens infames" que nos lembram da forma como o discurso desses pseudoautores, incorporados à análise do texto de 1969, se relacionam com a realidade. Encontramos, por meio da familiaridade entre a figura do autor e a figura do rei, o reconhecimento de funções que adquirem na história o estatuto de "reais" - no duplo sentido que, em francês, estaria cindido entre o réel e o royal. Porém, enquanto o status é uma forma de autoridade conferida pelos outros, portanto, que pressupõe reconhecimento atribuído a algo de que se fala, o poder, em vez disso, é uma partilha que serve a disputas alheias ao objeto tratado; ao ser acessado, ele é um subterfúgio gerador de outros interditos e de outras realizações e que distorce para sempre o objeto do relato. Toda memória produzida pelo contato com o poder partilha um status conferido anteriormente àquilo que é tratado e é, por ele, distorcida. O acontecimento explícito que aparece no discurso deixa de ser, assim, as ações relatadas para ser primariamente o ato de relatar em seu contexto político. A cada relato 
recuperado encontramos um caso que, mais do que surgir revelado em sua própria verdade, revela especificidades de uma prática vinculada a uma ética infame.

\footnotetext{
$\mathrm{O}$ que as arranca da noite em que elas teriam podido, e talvez sempre devido, permanecer é o encontro com o poder: sem esse choque, nenhuma palavra, sem dúvida, estaria mais ali para lembrar seu fugidio trajeto. (...) É, sem dúvida, para sempre impossível recuperá-las nelas próprias, tais como podiam ser "em estado livre" (FOUCAULT, 2006, p. 207-208).
}

Se a filosofia é composta de esclarecimentos estáveis a partir dos quais discernimos impressões seguras do mundo e, a cada vicissitude, confiamos um controle sobre nossas vidas, o pensamento de Michel Foucault dela não faz parte - fundamentalmente porque o que está em questão na filosofia para ele não é distinguir e apegar-se ao que é estável e seguro. Às vezes pode ser qualquer coisa de infame.

\section{Discurso e poder}

Como efeito da conjuntura até aqui introduzida, é preciso observar novas contraposições. Não mais a recôndita excelência da linguagem contra a superfície instrumental do discurso. O texto suscita outras dualidades: as falas toscas e as falas solenes; o campo da linguagem atravessado pela compaixão divina dos escolhidos e pelo repúdio aos hábitos dos miseráveis. Finalmente, o que está em questão no interesse de Foucault na análise desenvolvida nesse trabalho, para além dos elementos já vistos, é o "entrecruzamento" entre os discursos e os "mecanismos políticos".

Há dois aspectos que precisam ser analisados: o das consequências dos mecanismos políticos nos discursos, no que diz respeito à sua forma, e o das consequências dos discursos nos mecanismos políticos, portanto, o modo como os mecanismos políticos são exercidos como discurso. ${ }^{5} \mathrm{O}$ primeiro caso, como já dissemos, pode ser relacionado a uma questão estilística, ao modo como o discurso se ajusta, se conforma à rede política na qual ele surge. Não esperemos encontrar aí somente a solenidade. Para Foucault, há um "efeito cômico" nessa solenidade:

Efeito cômico, sem dúvida; há alguma coisa de irrisório ao se convocar todo o poder das palavras, e através delas a soberania do céu e da terra, em torno de desordens insignificantes ou de desgraças tão comuns: "Abatido sob o peso da mais excessiva dor, Duchesne, funcionário subalterno, ousa, com uma humilde e respeitosa 
confiança, lançar-se aos pés de Vossa Majestade para implorar sua justiça contra a mais malvada de todas as mulheres... Que esperança não deve conceber o desventurado que, encontrando-se em estado miserável, recorre hoje à Vossa Majestade depois de haver esgotado todas as vias de doçura, admoestações e deferência para reconduzir a seu dever uma mulher despojada de qualquer sentimento de religião, de honra, de probidade e mesmo de humanidade? Tal é, Sire, o estado do infeliz, que ousa fazer ressoar sua queixosa voz nas orelhas de Vossa Majestade." (FOUCAULT, 2006, p. 211).

Em segundo lugar, o efeito cômico pode surgir também da exacerbação da solenidade, do modo como por todos os artifícios se buscará adorná-la, mas pelos exemplos em que as tentativas se revelam fracassadas e patéticas.

Com frequência ocorria que as demandas fossem feitas por pessoas de muito baixa condição, pouco ou não alfabetizadas; elas próprias com seus magros conhecimentos ou, em seu lugar, um escriba mais ou menos hábil compunham, como podiam, as fórmulas e torneios de frase que pensavam requeridos quando alguém se dirige ao rei ou aos grandes, e os misturavam com as palavras maljeitosas e violentas, expressões rudes, através das quais elas pensavam, sem dúvida, dar às suas súplicas mais força e verdade. (...) Assim, fala a mulher de Nicolas Bienfait: ela "toma a liberdade de representar muito humildemente ao Sire que o dito Nicolas Bienfait, cocheiro de aluguel, é um homem extremamente devasso que a mata de pancada, e que tudo vende, tendo já causado a morte de suas duas mulheres, das quais a primeira ele lhe matou o filho dentro de seu corpo, e a segunda, depois de tê-la vendido e comido, por seus maus-tratos a fez morrer definhando, até querer estrangulá-la na véspera de sua morte... A terceira, ele quer comer-lhe o coração sobre a grelha, sem muitos outros assassinatos que fez; Sire, eu me jogo aos pés de Vossa Grandeza para implorar que o senhor me faça justiça, pois estando minha vida em risco a todo momento, não cessarei de orar ao Senhor pela conservação de vossa saúde" (FOUCAULT, 2006, p. 217-218).

Agora é preciso tratar não da conformidade do discurso ao poder, mas da imbricação, do modo como o poder é exercido pelo discursivo em suas múltiplas estratégias. Foucault analisa a passagem da prática religiosa de confissão, com a qual os homens se redimem de seus próprios pecados para uma série de procedimentos de investigação que pertencem a órgãos administrativos do Estado e que servem à apuração das pequenas verdades do cotidiano. Mas a questão não irá comparecer somente em "A vida dos homens infames".

Em $A$ verdade e as formas jurídicas, de 1973, encontramos um primeiro tratamento do problema. Nessa ocasião, lhe interessava os critérios com os quais verdades são reconhecidas dentro de um processo judicial. Entre essas formas, estariam a prova, o inquérito e o exame todas elas mecanismos que relacionam "a verdade", em suas "formas jurídicas", ao discurso. Um elemento em especial aproxima a conferência, de 1973, na PUC-Rio, à obra Vigiar e punir, de 1975, e ao texto de 1977 sobre os homens infames. É a referência às lettres de cachet. Que outro mecanismo mais arcaico de controle e vigilância há, mecanismo 
(predecessor do totalitarismo) que exige a participação da própria sociedade e de suas trocas discursivas? Foucault afirma em $A$ verdade e as formas jurídicas:

A lettre-de-cachet se apresenta, sob seu aspecto de instrumento terrível da arbitrariedade real, investida de uma espécie de contra poder, poder que vinha de baixo e que permitia a grupos, comunidades, famílias ou indivíduos exercer um poder sobre alguém. Eram instrumentos de controle, de certa forma espontâneos, controle por baixo, que a sociedade, a comunidade, exercia sobre si mesma. (FOUCAULT, 2009, p. 96-97).

Em “A vida dos homens infames", encontraremos uma passagem muito semelhante:

\begin{abstract}
As "ordens do rei" não baixavam de improviso, de cima para baixo, como signos da cólera do monarca, senão nos casos mais raros. Na maior parte do tempo elas eram solicitadas contra alguém por seus familiares, seu pai e sua mãe, um de seus parentes, sua família, seus filhos ou filhas, seus vizinhos, às vezes o padre local, ou algum membro representativo. (...) A lettre de cachet com ordens de prisão, tida como a vontade expressa e particular do rei de fazer encarcerar um de seus súditos, fora das vias da justiça regular, não era senão a resposta a essa demanda vinda de baixo. (FOUCAULT, 2006, p. 214).
\end{abstract}

O povo, que fora considerado na análise da modernidade em As palavras e as coisas a fonte da linguagem ainda em seus balbucios radicais e menos discerníveis, agora disperso participa dos mecanismos de poder exercidos por meio do discurso. Ele suplica, e assim adapta a sua fala tosca à fala solene dos nobres, tornando-se sujeito patético, estranho na linguagem, mas ele a serve também de outros modos: ele confessa; ele testemunha; ele denuncia; ele delata.

Apenas um ano antes de "A vida dos homens infames", Foucault publica História da sexualidade I: a vontade de saber. Nessa obra, encontramos a análise mais profunda da questão da confissão como experiência primeira de controle sobre a vida pelo discurso, o que será reconhecido como a origem de mecanismos administrativos de averiguação da verdade. Nela, Foucault não trabalha com a hipótese repressiva, do silêncio. Ele repete insistentemente que a história da sexualidade demonstra que a relação com o sexo não foi, ao longo dos últimos séculos, essencialmente repressiva, uma vez que, ao contrário, diversos dispositivos surgiram a partir do século XVIII com o fim de fazer com que as pessoas falassem sobre o sexo, que confessassem seus desejos e suas práticas. ${ }^{6}$ Porque conscientes de que haveriam de confessá-las, eles se constrangiam a realizá-las. O lugar do discurso em História da sexualidade I se baseia na análise das formas como o silêncio sobre o sexo foi transformado em confissão sobre o sexo. A confissão religiosa se transforma em confissão de todas as 
infrações do cotidiano, revelando-se em nossos dias, finalmente, uma experiência radical para o que somos: "Tanto a ternura mais desarmada quanto os mais sangrentos poderes têm necessidade de confissões. O homem, no Ocidente, tornou-se um animal confidente." (FOUCAULT, 2006, p. 68).

Dessa experiência de revelação do cotidiano surge a noção de "vontade de saber", na verdade já presente em $A$ ordem do discurso, de 1970, e no primeiro curso de Foucault no Collège de France, Lições sobre a vontade de saber. O que está por trás do saber produzido pela confissão é uma "vontade" de tudo revelar. A vontade de saber não é uma instância metafísica, mas o conjunto de práticas que tornam público, explícito, o que diz respeito à intimidade, à individualidade, à privacidade. ${ }^{7}$ Em 1976, no curso Em defesa da sociedade, segundo um mesmo interesse de investigação, Foucault afirma: “Gostaria de passar em revista não só esses discursos, mas ainda a vontade que os conduz e a intenção estratégica que os sustenta." (FOUCAULT, 2006, p. 15) Não há em toda vontade de saber, realizada em estratégias de poder, a busca de revelar toda a infâmia secreta no que há de mais ínfimo na vida cotidiana? Não estaria o arcabouço conceitual de Foucault, antes do estudo da Askesis grega, a prática de si, do governo de si, voltado para a tarefa de denunciar a vigência de uma ética da infâmia?

Finalmente, se vimos em "A vida dos homens infames" um importante entrecruzamento, que necessariamente pressupõe uma implicação, um favorecimento mútuo, uma simbiose entre discurso e poder, devemos também considerar outro estranho caso, não examinado naquele texto, mas considerado em História da sexualidade I, e que será muito importante para o desenvolvimento futuro do pensamento de Foucault, em particular quanto à noção de Pahrresía, a coragem de dizer a verdade, a fala franca. Trata-se do paradoxal caso de não simbiose em que o discurso vem atuar contra o poder. Neste, o discurso não se adapta ao poder nem é utilizado por ele, servindo-lhe, mas vem confrontá-lo. Esse caso nos permite considerar a iminência de um corte nas reflexões do autor, pois, para Foucault, a esse momento o poder pode ser tanto o polo, a força dominante que o discurso viria desafiar, como pode ser a rede em que é travada a guerra contínua entre as forças e onde são decididas as suas sucessivas trocas de posição. Qual é, então, o sentido de se falar de um discurso contra o poder se o poder é sempre uma relação contrária de forças? Aí estaria talvez o problema que marcará a passagem do desafio de denunciar a ética da infâmia para o desafio de propor uma outra ética, fundada no resgate da Askesis grega. Aí estão também as sementes dos desenvolvimentos futuros da análise do discurso e do poder, em direção à Pahrresia. 
Fiquemos com a sua sinalização primeira, o marco entre a ética que herdamos e aquela em que podemos empenhar a nossa liberdade:

Os discursos, como os silêncios, nem são submetidos de uma vez por todas ao poder, nem opostos a ele. É preciso admitir um jogo complexo e instável em que o discurso pode ser, ao mesmo tempo, instrumento e efeito do poder, e também obstáculo, escora, ponto de resistência e ponto de partida de uma estratégia oposta. O discurso veicula e produz poder; reforça-o, mas também o mina, expõe, debilita e permite barrá-lo. (FOUCAULT, 2006, p. 111-112). 


\section{Notas}

\footnotetext{
${ }^{1}$ Este artigo foi produzido como parte de uma pesquisa de doutorado e de doutorado sanduíche com o apoio respectivamente do $\mathrm{CNPq}$ e da Capes.

2 Professor de graduação e pós-graduação em Filosofia na Universidade São Judas Tadeu (USJT), São Paulo, Brasil. Doutor em Filosofia pela Pontifícia Universidade Católica do Rio de Janeiro (PUC-Rio), com experiência de estágio de pesquisa sanduíche na Université Paris 1 Panthéon-Sorbonne.
}

3 "Vidas singulares, tornadas, por não sei quais acasos, estranhos poemas, eis o que eu quis juntar em uma espécie de herbário”. (FOUCAULT, 2006, p. 204)

4 "Mas se o gosto que tenho por eles há anos não foi contradito e se retorno a eles ainda é porque conjecturo um começo; em todo caso, um acontecimento importante em que se cruzaram mecanismos políticos e efeitos de discurso". (FOUCAULT, 2006, p. 211)

5 “Como o poder seria leve e fácil, sem dúvida, de desmantelar, se ele não fizesse senão vigiar, espreitar, surpreender, interditar e punir; mas ele incita, suscita, produz; ele não é simplesmente orelha e olho; ele faz agir e falar" (FOUCAULT, 2006, p.219-220).

6 "Através de tais discursos multiplicaram-se as condenações judiciárias das perversões menores, anexou-se a irregularidade sexual à doença mental; da infância à velhice foi definida uma norma do desenvolvimento sexual e cuidadosamente caracterizados todos os desvios possíveis; organizaram-se controles pedagógicos e tratamentos médicos, trouxeram à baila todo o vocabulário enfático da abominação: isso não equivaleria a buscar meios de reabsorver em proveito de uma sexualidade centrada na genitalidade tantos prazeres sem fruto?” (FOUCAULT, 2006, p. 43).

7 Tal análise converge com aquela realizada duas décadas antes por Hannah Arendt em $A$ condição humana, no que compete ao diagnóstico da ascensão da esfera social, onde ocorre a sobreposição entre os domínios público e privado. 


\section{Referências bibliográficas}

BORGES, J. L. História universal da infâmia. Trad. F. J. Cardozo. Porto Alegre: Editora Globo, 1978.

CHEVALLIER, P. Le pouvoir et la bataille, Nantes: Éditions pleins feux, 2004.

DELEUZE, G. Foucault. Trad. Claudia Sant'anna Martins. São Paulo: Brasiliense, 2008.

ERIBON, D. Michel Foucault. Trad. H. Faist. São Paulo: Companhia das letras, 1990.

FOUCAULT, M. "A vida dos homens infames" in: Ditos e escritos, v. 4. Trad. Vera Lucia Avelar Ribeiro. Rio de Janeiro: Forense universitária, 2006.

. “O que é um autor?" in: Ditos e escritos, v. 3. Trad. Inês Autran Dourado Barbosa. Rio de Janeiro: Forense universitária, 2009. 2008

. A arqueologia do saber. Trad. L. F. B. Neves. Rio de Janeiro: Forense Universitária,

. A hermenêutica do sujeito. Trad. M. A. Fonseca e S. T. Muchail. São Paulo: Martins fontes, 2006.

. A ordem do discurso. Trad. L. F. A. Sampaio. São Paulo: Edições Loyola, 2012.

. A verdade e as formas jurídicas. Trad. R. Machado e E. Jardim. Rio de Janeiro: NAU editora, 2009.

. As palavras e as coisas. Trad. S. T. Muchail. São Paulo: Martins fontes, 2002.

.Em defesa da sociedade. Trad. M. E. Galvão. São Paulo: Martins fontes, 2005.

. História da loucura na idade clássica. Trad. J. T. Coelho Neto. São Paulo: Perspectiva, 2005.

História da sexualidade. v. 1. Trad. M. T. Albuquerque e J. A. Albuquerque. São Paulo: Graal, 2006.

. Nascimento da biopolítica. Trad. Eduardo Brandão. São Paulo: Martins Fontes, 2008.

. Vigiar e punir. Trad. Raquel Ramalhete. Petrópolis: Vozes, 2008.

Recebido / Received: 08/03/2014

Aprovado / Approved: 30/06/2014 